\title{
Seed Transmission Rates of Bean pod mottle virus and Soybean mosaic virus in Soybean May Be Affected by Mixed Infection or Expression of the Kunitz Trypsin Inhibitor
}

\author{
Moon Nam¹, Hanhong Bae ${ }^{2}$, John Hammond ${ }^{3}$, Leslie L. Domier ${ }^{4,5}$, Young-Nam Youn ${ }^{1}$, \\ Bong-Choon Lee ${ }^{6 *}$ and Hyoun-Sub Lim ${ }^{1 *}$ \\ ${ }^{1}$ Department of Applied Biology, Chungnam National University, Daejeon 305-764, Korea \\ ${ }^{2}$ School of Biotechnology, Yeungnam University, Geongsan 712-749, Korea \\ ${ }^{3}$ Floral and Nursery Plants Research Unit, United States Department of Agriculture-Agricultural Research Service, \\ Beltsville, MD 20705, United States of America \\ ${ }^{4}$ Department of Crop Sciences University of Illinois, 1102 Goodwin Avenue, Urbana, IL 61801, United States of America \\ ${ }^{5}$ United States Department of Agriculture-Agricultural Research Service, 1102 South Goodwin Avenue, Urbana, \\ IL 61801, United States of America \\ ${ }^{6}$ Crop Environment Research Division, National Institute of Crop Science, Rural Development Administration, \\ Suwon 441-857, Korea
}

(Received on May 15, 2013; Revised on June 1, 2013; Accepted on June 4, 2013)

\begin{abstract}
To facilitate their spread, plant viruses have developed several methods for dispersal including insect and seed transmission. While insect transmission requires virus stability against insect digestion, seed-transmitted viruses have to overcome barriers to entry into embryos. Bean pod mottle virus (BPMV) is transmitted through seed at levels typically below $0.1 \%$, but co-infection with Soybean mosaic virus (SMV) enhanced the seed transmission rate of BPMV in one experiment. In contrast, the rate of SMV seed transmission was not affected by BPMV co-infection. In a second preliminary study, the rate of SMV transmission was lower in an isoline of Williams 82 that contained a null mutation for the Kunitz trypsin inhibitor gene than in Williams 82. In this preliminary study, we observed that factors such as protease inhibitor expression and dual infection may affect the frequency of seed transmission of BPMV and SMV.
\end{abstract}

Keywords : BPMV, Dual infection, ELISA, Kunitz, Seed transmission, SMV

Dual infection of soybean by Soybean mosaic virus (SMV) and Bean pod mottle virus (BPMV) induces severe symptoms and increases BPMV RNA titers, whereas SMV titers in the mixed infections are similar to those in SMV single infections (Anjos et al., 1992; Lim et al., 2011). Synergism is frequently associated with mixed infection of a potyvirus and an unrelated virus, with enhanced symptoms and higher titer of the other virus than in single infections resulting from the strong silencing suppressor function of the potyviral helper component protease (HC-Pro) (Pruss et al., 1997).

\footnotetext{
*Corresponding author, Hyoun-Sub Lim

Phone) +82-42-821-5766, Fax) +82-42-823-8679

Email) hyounlim@cnu.ac.kr

*Corresponding author, Bong-Choon Lee

Phone) +82-31-290-6791, Fax) +82-31-290-6773

Email) leebc21@korea.kr
}

SMV HC-Pro functions to sequester small interfering RNAs and thus stabilize the genomic RNA of the coinfecting virus, which expresses a weak or functionally different RNA silencing suppressor (Lim et al., 2011). HC-Pro is a multifunctional protein and has been studied to understand its role in virus movement, aphid transmission and suppression of RNA silencing (Blanc et al., 1997; Blanc et al., 1998; Cronin et al., 1995; Rojas et al., 1997; Varrelmann et al., 2007). SMV seed transmission rates range from $0 \%$ to $75 \%$ in a cultivardependent manner (Bos, 1972; Bowers, 1977; Cho, 1976; Cho et al., 1977; Clark and Perry, 2002; Hill et al., 2001). In contrast to SMV, BPMV has been reported to be transmitted through seed at very low levels, usually less than 0.1\% (Hobbs et al., 2003; Lin and Hill, 1983; Ross, 1986). The HC-Pro coding region of Pea seed-borne mosaic virus (PSbMV) was necessary for seed transmission (Johansen et al., 1996). Recently, HC- 
Pro and the DAG motif in the coat protein (CP) of SMV were shown to be important for efficient seed transmission of SMV (Jossey et al., 2012). High rates of SMV seed transmission were associated with HC-Pro silencing suppressor function, and mutations in HC-Pro abolished SMV seed transmission.

In addition to protection of viral RNA by suppression of RNA silencing by HC-Pro, Bowers and Goodman (1991) suggested that survival of the virus within the maturing embryo plays an important role in seed transmission. The soybean Kunitz trypsin inhibitor gene is expressed in soybean seed during seed development. During seed development the precursor protein is cleaved in two stages to yield the mature Kunitz inhibitor by cleavage of a 25-residue $\mathrm{N}$-terminal precursor peptide, and an eleven residue C-terminal peptide (Goldberg et al., 1981; McGrain et al., 1992; Walling et al., 1986). Protease inhibitors have been proposed to function as regulators of endogenous proteases in seed and to protect plants from insect attack (Ryan, 1981).

In this study, we focused on whether SMV could enhance seed transmission of BPMV in doubly infected soybean plants, which may be explained by assistance from HC-Pro and CP of SMV that are well adapted for seed transmission. We also evaluated the possible role in seed transmission of SMV of one of the proteinase inhibitors expressed in maturing soybean embryos, Kunitz trypsin inhibitor, by comparing SMV seed transmission in soybean cultivar Williams 82 and an isolate that was null for expression of Kunitz trypsin inhibitor.

In order to investigate the ability of SMV to enhance the seed transmissibility of BPMV, isolates BPMV 98 and SMV G5 were used. BPMV 98 was obtained from a field collection in Illinois, and SMV strain G5 was obtained from John Hill at Iowa State University. Plant introduction (PI) 157440 soybean seeds were obtained from the USDA soybean germplasm center (Urbana, Illinois), which transmits SMV through seed at high rates, was inoculated with BPMV and BPMV plus SMV. Soybeans were planted in $25 \mathrm{~cm}$ pots containing soil/ Sunshine Mix 50:50 in a greenhouse. Young, symptomatic soybean leaves macerated $1: 10(\mathrm{w} / \mathrm{v})$ in $0.05 \mathrm{M}$ sodium phosphate buffer, $\mathrm{pH} 6.9$ were used to inoculate the seedlings. Unifoliate leaves were dusted with 600 mesh Carborundum and rubbed with gauze pads dipped in inoculum. Plants were arranged in a completely random design on greenhouse benches and grown under $14 \mathrm{hr}$ daylight $\left(100-180 \mu \mathrm{Em}^{-2} \mathrm{~s}^{-1}\right)$. To investigate seed transmission rate of BPMV, harvested seeds were planted in 96-well trays, and germinated seedlings were tested by enzyme-linked immunosorbent assay (ELISA) using antibodies and protocols from AgDia (Elkhart, IN, USA).
Leaf extracts for ELISA were homogenized with phosphate buffered saline (PBS) containing $0.02 \mathrm{M} \mathrm{NaCl}, 2.0 \%$ polyvinyl pyrrolidone MW 40,000, 0.05\% Tween-20, and $0.02 \%$ sodium azide. Samples were read using an MRX microplate reader with optical density at $405 \mathrm{~nm}$ (Dynex, Denhendorf, Germany).

From 645 seedlings that originated from seeds of soybean plants infected with BPMV and SMV, two seedlings were enzyme-linked immunosorbent assay (ELISA) positive for BPMV (0.31\% seed transmission rate) but negative for SMV, which indicated transmission of BPMV through seed to the developing seedling. Even though these two seedlings were ELISA negative for SMV, they were stunted and leafless, and died. Sixty-two of the 645 seedlings from the same seed of soybean plants infected with SMV and BPMV were ELISApositive for SMV indicating a 9.6\% SMV seed transmission rate. There were no seedlings positive for both SMV and BPMV. Meanwhile, 650 seedlings germinated from plants infected with BPMV alone did not show the positive ELISA reaction (Table 1). About $0.31 \%$ of BPMV seed transmission rate detected from among 645 double infected seedlings was higher than $0.1 \%$ seed transmission rate which is reported in the previous study (Hobbs et al., 2003; Lin and Hill, 1983; Ross, 1986). These data indicated BPMV seed transmission rate could be higher in soybean in case of dual infection with SMV.

In addition to the increase in the seed transmission rate resulting from dual infection, the environment during seed development may influence the survival rate of virus inside seed. To compare seed transmission rates among soybean genotypes differing in the levels of proteinase inhibitors expressed during embryogenesis, we examined whether trypsin inhibitor expression affects SMV seed transmission. To investigate how trypsin

Table 1. Seed transmission of seedlings from Bean pod mottle virus (BPMV)-infected seeds and Soybean mosaic virus (SMV) plus BPMV-infected seeds

\begin{tabular}{cccc}
\hline \hline \multicolumn{4}{c}{ Seed transmission } \\
\hline $\begin{array}{c}\text { Single infection } \\
\text { (650 seeds) }\end{array}$ & \multicolumn{3}{c}{$\begin{array}{c}\text { Double infection } \\
(645 \text { seeds })\end{array}$} \\
\hline BPMV $^{\mathrm{a}}$ & BPMV & SMV & Double \\
\hline $0^{\mathrm{b}}$ & 2 & 62 & 0 \\
$0 \%{ }^{\mathrm{c}}$ & $0.3 \%$ & $9.6 \%$ & $0 \%$ \\
& & $9.9 \%{ }^{\mathrm{d}}$ & \\
\hline
\end{tabular}

\footnotetext{
${ }^{a}$ BPMV ELISA positive control.

${ }^{b}$ Number of positive seedlings.

c\% seed transmission.

d\% (either SMV or BPMV) of seed transmission.
} 
Table 2. Seed transmission of Soybean mosaic virus (SMV) in Kunitz soybean trypsin inhibitor soybean isolines

\begin{tabular}{lcc}
\hline \hline & William 82 & $\begin{array}{c}\text { Kunitz(-), } \\
\text { L81-4590 }\end{array}$ \\
\hline Seed number & 179 & 190 \\
SMV positive ELISA positive & 12 & 4 \\
\% of seed transmission & $6.7 \%$ & $2 \%$ \\
\hline
\end{tabular}

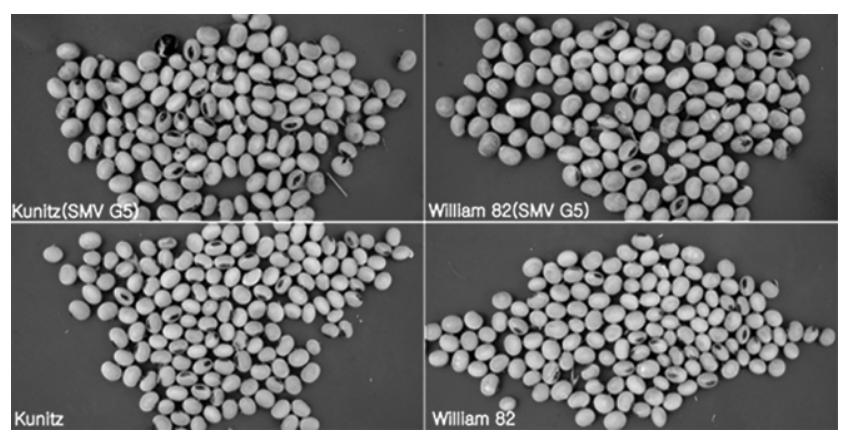

Fig. 1. Seed quality from Soybean mosaic virus G5 infected William 82 and Kunitz soybean trypsin inhibitor isolines.

inhibitor affects SMV seed transmission, we used a soybean isogenic line, L81-4590 that lacked detectable levels of the Kunitz trypsin inhibitor and was derived by backcrossing PI 157440 to Williams 82 (Hymowitz, 1986). L81-4590 produced less than $0.2 \%$ of the protease inhibitor activity found in Williams 82 (Friedman et al., 1991). Williams 82 and L81-4590 seedlings were inoculated with SMV G5, and seeds were collected.

Twelve seedlings were positive for SMV from a total of 179 germinated seeds of Williams 82, and 4 were positive for SMV out of 190 L81-4590 seeds (Table 2). Seed quality was low from both SMV G5-infected lines (Fig. 1). Hence, there was a higher rate of seed transmission $(6.7 \%$ vs. $2.1 \%)$ from Williams 82 than from Kunitz(-) isoline. This result could be explained by expression of the Kunitz trypsin inhibitor present in Williams 82 enhancing virus survival inside seed. Therefore, low protease activity in William 82 seeds resulting from expression of the Kunitz trypsin inhibitor appears to enable SMV to survive at a higher rate than SMV in L81-4590 which presumably had higher concentrations of active tryptic proteases. SMV has been reported to be a highly seed transmissible virus in susceptible cultivars. Our preliminary findings suggest that different levels of Kunitz trypsin inhibitor gene expression during seed development can influence seed transmission.

Consistent with previous reports indicating that SMV HC-Pro and CP have important roles in seed transmission, we found evidence that the strong silencing suppressor and $\mathrm{CP}$ expressed by SMV may enhance seed transmission of BPMV, which expresses a weak silencing suppressor. In addition, we found evidence that proteinase inhibitors expressed during embryo development enhanced seed transmission of SMV, which may be related to virus survival inside maturing seed.

\section{Acknowledgement}

This research was supported by IPET (Korea Institute of Planning and Evaluation for Technology in Food, Agriculture, Forestry and Fisheries for which this work was funded under grant no: 112018-03-1-SB010), Ministry for Food, Agriculture, Forestry and Fisheries, Republic of Korea.

\section{References}

Anjos, J. R., Jarlfors, U. and Ghabrial, S. A. 1992. Soybean mosaic potyvirus enhances the titer of two comoviruses in dually infected soybean plants. Phytopathology 82: 10221027.

Blanc, S., Lopez-Moya, J. J., Wang, R., Garcia-Lampasona, S., Thornbury, D. W. and Pirone, T. P. 1997. A specific interaction between coat protein and helper component correlates with aphid transmission of a potyvirus. Virology 231: 141-147.

Blanc, S., Ammar, E. D., Garcia-Lampasona, S., Dolja, V. V., Llave, C., Baker, J. and Pirone, T. P. 1998. Mutations in the potyvirus helper component protein: effects on interactions with virions and aphid stylets. J. Gen. Virol. 79: 3119-3122.

Bos, L. 1972. Soybean mosaic virus. No. 93 in Descriptions of Plant Viruses. Commonw. Mycol. Inst., Assoc. Appl. Biologists, Kew, Surrey, England.

Bowers, G. R. 1977. Seed transmission of Soybean mosaic virus. M.S. Thesis, University of Illinois, Urbana.

Bowers, G. R. and Goodman, R. M. 1991. Strain specificity of Soybean mosaic virus seed transmission in soybean. Crop Sci. 31: 1171-1174.

Cho, E. K. and Chung, B. J. 1976. Studies on identification and classification of soybean virus disease. Korean J. Plant Prot. 15: 61-68. (In Korean)

Cho, E. K., Chung, B. J. and Lee, S. H. 1977. Studies on identification and classification of soybean virus diseases in Korea. II. Etiology of a necrotic disease of Glycine max. Plant Dis. Rep. 61: 313-317.

Clark, A. J. and Perry, K. L. 2002. Transmissibility of field isolates of soybean viruses by Aphis glycines. Plant Dis. 86: 1219-1222.

Cronin, S., Verchot, J., Haldeman-Cahill, R., Schaad, M. C. and Carrington, J. C. 1995. Long-distance movement factor: A transport function of the potyvirus helper component proteinase. Plant Cell 7: 549-559. 
Friedman, M., Brandon, D., Bates, A. and Hymowitz, T. 1991. Comparison of a commercial soybean cultivar and an isoline lacking the kunitz trypsin inhibitor: Composition, nutritional value, and effects of heating. J. Agric. Food Chem. 39: 327335 .

Goldberg, R. B., Hoschek, G., Ditta, G. S. and Breidenbach, R. W. 1981. Developmental regulation of cloned superabundant embryo mRNA in soybean. Dev. Bio. 83: 218-231.

Gu, H., Clark, A. J., Pfeiffer, T. W., Tolin, S. and Ghabrial, S. A. 2002. Diversity among isolates of bean pod mottle virus. Phytopathology 92: 446-452.

Hill, J. H., Alleman, R., Hogg, D. B. and Grau, C. R. 2001. First report of transmission of Soybean mosaic virus and Alfalfa mosaic virus by Aphis glycines in the new world. Plant Dis. 85: 561 .

Hobbs, H. A., Hartman, G. L., Wang, Y., Hill, C. B., Bernard, R. L., Pedersen, W. L. and Domier, L. L. 2003. Occurrence of seed coat mottling in soybean plants inoculated with Bean pod mottle virus and Soybean mosaic virus. Plant Dis. 87: 13331336.

Hymowitz, T. 1986. Genetics and breeding of soybeans lacking the Kunitz trypsin inhibitor. In: Nutritional and toxicological significance of enzyme inhibitors in foods, ed. by Friedman, M., pp. 291-298. Plenum Press, New York.

Johansen, I. E., Dougherty, W. G., Keller, K. E., Wang, D. and Hampton, R. O. 1996. Multiple viral determinants affect seed transmission of pea seedborne mosaic virus in Pisum sativum. J. Gen. Virol. 77: 3149-3154.

Jossey, S. 2012. Role of virus genes in seed and aphid transmission and development of a virus-induced gene silencing system to study seed development in soybean. Ph.D. thesis. University of Illinois, Urbana, USA.

Lim, H. S., Jang, C., Bae, H., Kim, J., Lee, C., Hong, J., Ju, H.,
Kim H. and Domier, L. L. 2011. Soybean mosaic virus infection and helper component-protease enhance accumulation of bean pod mottle virus-Specific siRNAs. Plant Pathology J. 27: $315-323$.

Lin, M. T. and Hill, J. H. 1983. Bean pod mottle virus: occurrence in Nebraska and seed transmission in soybeans. Plant Dis. 67: 230-233.

McGrain, A. K., Chen, J. C., Wilson, K. A. and Tan-Wilson, A. 1992. Proteases catalysing processing and degradation of kunitz soybean trypsin inhibitor during seed maturation. Phytochem. 31: 421-426.

Pruss, G., Ge, X., Shi, X. M., Carrington, J. C. and Vance, V. B. 1997. Plant viral synergism: The potyviral genome encodes a broad-range pathogenicity enhancer that transactivates replication of heterologous viruses. Plant Cell 9: 859-868.

Rojas, M. R., Zerbini, F. M., Allison, R. F., Gilbertson, R. L. and Lucas, W. J. 1997. Capsid protein and helper componentproteinase function as potyvirus cell-to-cell movement proteins. Virology 237: 283-295.

Ross, J. P. 1986. Response of early- and late-planted soybeans to natural infection by bean pod mottle virus. Plant Dis. 70: $222-$ 224.

Ryan, C. A. 1981. Proteinase inhibitors. In: Biochemistry of plants. ed by A. Marcus. New York, Academic Press, Vol. 6. pp. 351-370.

Varrelmann, M., Maiss, E., Pilot, R. and Palkovics, L. 2007. Use of pentapeptide-insertion scanning mutagenesis for functional mapping of the plum pox virus helper component proteinase suppressor of gene silencing. J. Gen. Virol. 88: 1005-1015.

Walling, L., Drews, G. N. and Goldberg, R. B. 1986. Transcriptional and post-transcriptional regulation of soybean seed protein mRNA levels. Proc. Natl. Acad. USA 83: 2123-2127. 